\title{
A review of European sovereign debt crisis: Causes and consequences
}

\author{
G. M. Wali Ullah, Samiul Parvez Ahmed \\ School of Business, Independent University, Bangladesh (IUB), Dhaka, Bangladesh \\ Email address: \\ wali@iub.edu.bd (G. M. Wali. Ullah), samiul@iub.edu.bd (S. P. Ahmed)
}

\section{To cite this article:}

G. M. Wali Ullah, Samiul Parvez Ahmed. A Review of European Sovereign Debt Crisis: Causes and Consequences. International Journal of Business and Economics Research. Vol. 3, No. 2, 2014, pp. 66-71. doi: 10.11648/j.ijber.20140302.13

\begin{abstract}
This paper researched on the causes, current consequences and potential implication of the European debt crisis. The crisis was found to be a result of factors including international trade imbalances, the effects from the global crisis 2007-2012 and the failure in bailout approaches to cure Europe from the global financial distress. This has caused panic across the world due to the fact that negative financial situations in peripheral countries in Europe might further demolish the global financial markets. Even though significant growth was presumed from the introduction of Euro, the financial crisis resulted in sharp rise in bond yields, CDS, cross-correlation and spillover effects across bond markets of the Eurozone. Yield curves of the GIIPS countries acted as a cluster; differentiating from stronger and more stable economic forces. In addition, crisis resulted in significant dip of market confidence on Euro and depreciation of Euro against major currencies. Commodity prices i.e. spot price of gold rose to almost $300 \%$ over the time crisis period, utilized by governments as a defense mechanism against the economic downturns. Potential problems that might arise from this severe crisis and financial prospects of European states as well as governments over the world are also assessed and discussed.
\end{abstract}

Keywords: Sovereign Debt, Eurozone Crisis, GIIPS, Sovereign Default

\section{Introduction}

The Economic Integration of twenty seven European countries, which was initially established in 1993, collectively identified as the Eurozone, aims at stimulating its members' economic growth, encouraging industrial specialization and further boosting supplemental gains from international trade. The Eurozone had subsequent integration with another seventeen member nations of the European Union, agreeing to adopt the Euro as their common currency and legal tender. However, an unceasing sovereign debt crisis which boomed in late 2008 and early 2009 brought the European common currency area into distress, arising from the need of refinancing their government debts. Eurozone's public debts amounted to $85.3 \%$ of its GDP in 2010 and were expected to rise steadily to $89 \%$ in 2012 [1].

This sovereign debt crisis has threatened European financial into facing a new recession. Thus, it is necessary to have a comprehensive understanding on why and how this crisis considerably influenced global financial markets. This paper aims to look at the causes and the consequences of the European crisis on the bond market as well as equity, derivatives, commodities, FOREX markets, to name but a few. Besides, it also focuses on examining the austerity measures and policies taken by European governments to bail their countries out of the turmoil.

\section{European Debt Crisis: The Causes}

There are a number of factors that led to the European sovereign debt crisis. These factors ranges from a combination of international trade imbalances, the impact of the global crisis from 2007 to 2012, failure in bailout approaches of European governments that troubled banking industries and private bondholders and high-risk lending and borrowing policies enforced by unrestricted credit requirements during the period from 2002 to 2008 [2]. These loosely controlled practices further caused a real estate bubble in Europe, which drew the situation closer to a financial crisis [3, 4].

Starting from Greece, Ireland, Portugal, Spain and more recently, Italy, collectively referred as GIIPS, the European debt crisis was an agonizing consequence of excessive lending that had left banks with bad debts and governments with huge fiscal deficit and public debts in the perimeter 
economies [5]. From an accounting point of view, the introduction of the Euro was blamed as the cause that made it possible for European nations to borrow at much lower costs than before [6]. The reason is that although they are still the debts of the individual nations alone, the risk is assessed to be lower due to the economic rules they complied with by being members of the EU.

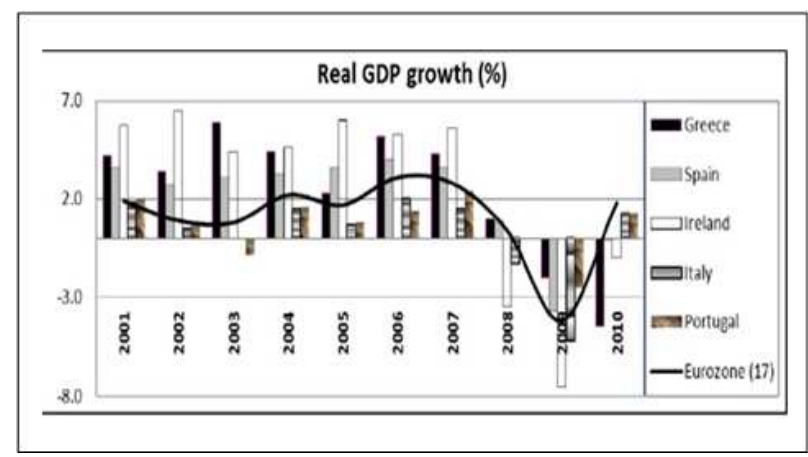

Figure 1. Real GDP Growth (\%) (Source: [1])

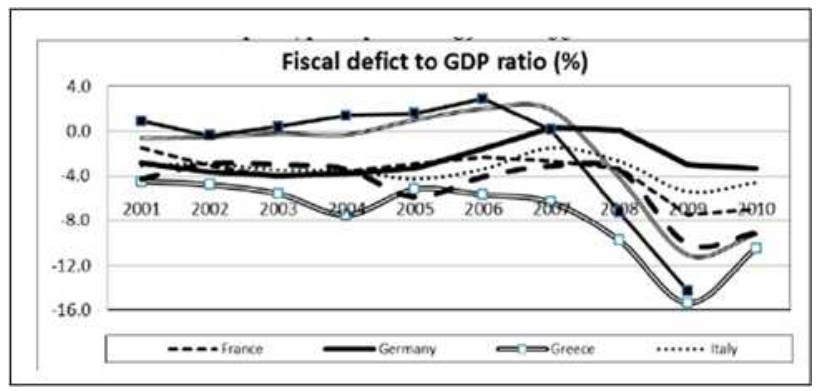

Figure 2. Fiscal Deficit to GDP Ratio (Source: [1])

These regulations required Eurozone members to limit their government debt level and budget deficit at $60 \%$ and $3 \%$ of their GDP correspondingly. However, GIIPS used most of their available credits in larger consumption, building generous social systems and further funding a construction boom, which resulted in enormous government budget deficits that were not sustainable. Apparently, figure 2 shows a negative side of fiscal deficit of most European countries in which Greece plunged at $16 \%$ of its total GDP in 2009. As a result, credit rating for sovereign debt of these countries was downgraded. This move not only led to a significant increase in their borrowing cost and a massive plunge in investor confidence on sovereign default in 2009 but also threatened other European economies and even the future of their common currency [5].

Another reason that contributed to the financial crisis in Europe is the gap of economic strength and structure between GIIPS and other members in the common currency area. From 2006, the interest rates across Eurozone started to diverge, marking out the weak and strong economies, as can be seen in figure 3 :

In addition, the global financial distress in 2007, which triggered the European debt crisis, caused many problems with liquidity of European banks that sharply faltered lending and economic growth. Due to the credit boom during 2003-2007 periods that was encouraged by declining interest rates; the loans to governments and private organizations grew dramatically and gave rise to obstacles in repaying and servicing those debts.
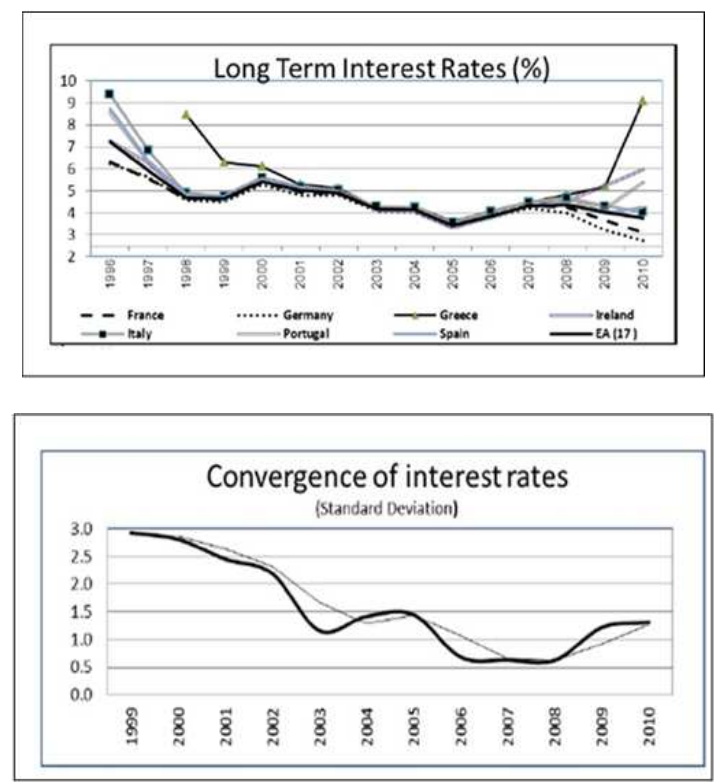

Figure 3. Long Term Interest Rates \& its Convergence (\%) (Source: [1])

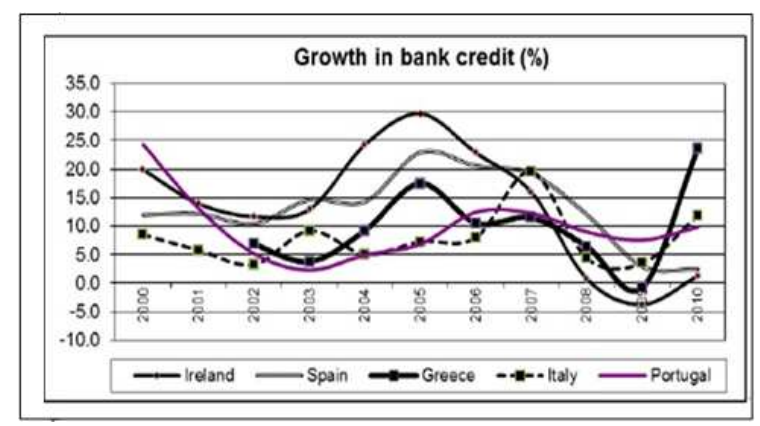

Figure 4. Growth in Bank Credit (\%) (Source: IMF)

Finally, the lack of firm and decisive action by Eurozone nations and institutions was claimed to be a major factor contributing to the crisis. Since the EU was established without a channel for a country to leave the unity, its members such as Greece and Spain gave up control on their own monetary policy. Thus, they lost the capability of devaluing their own currency and fiscal regulations flexibility to take immediate action to resolve their own situation before European Central Bank's bailouts packages for individual states were approved.

\section{Impact of Crisis on the Financial Markets}

\subsection{Financial Crisis' Impacts on the Global Economy}

The Eurozone financial chaos has caused a number of problems for European countries in refinancing their public 
liabilities arising from 2002 to 2008 as a result of high-risk lending and borrowing practices. Because of the fact that Europe is a huge financial market and it plays an important role of business and financial partners of other major world economic powers i.e. USA and UK, its economic turbulence also damaged banks and pension funds all over the world [7]. As a domino effect, a widespread panic was experienced around the global financial markets, including bond, equity and many other types of markets. Moreover, bail-out packages of IMF and European Central Bank in order to pull Europe out of the crisis and the tremendous uncertainties and volatility of the economic circumstances in developed countries also contributed to the mass financial havoc for the time being [8].

\subsection{Effects on Bond Markets}

First issued by the Bank of England to raise funds for war against France back in 1693, sovereign bonds are considered by investors as almost risk free assets under the assumption that governments are too big to fail and default on coupon payments of these instruments. In the event of financial difficulty, governments are expected to raise taxes, create money supply and take other measures to pay off the debts [9].

Euro, as the common currency across on the Eurozone block was introduced with the belief that, the greater fiscal and monetary union across countries will guaranty fiscal harmonization and solvency among these countries. Before the crisis, bond rates and CDS for Eurozone members were below what would be expected. However when the crisis erupted, both these indicators rose more sharply for Eurozone members than predicted based on their available fiscal space [9]. The introduction of the Euro has strengthened the volatility spillover effects and the cross-correlations for most European bond markets [11].

Bond indices represent country economic health to a large degree, since bonds are essentially government debts. Investors became increasingly worried about negative self-fulfilling market sentiments about the bond market of the Eurozone, and reacted by raising the spreads [12].

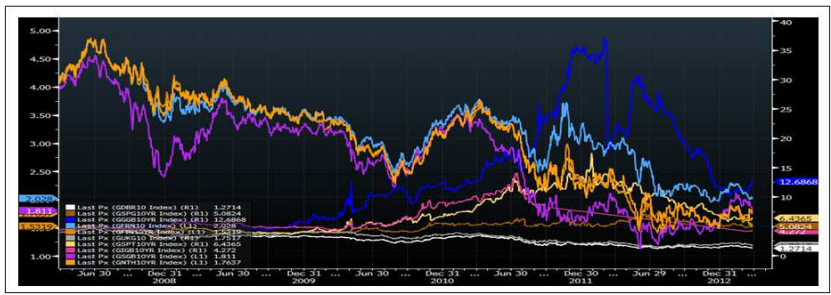

Figure 5. Government bond indices (Source: Bloomberg)

A look at the following bond index movements over long term time period clearly distinguishes countries together in two clusters after the eruption of crisis. Due to bonds being rated as junks by credit rating agencies, yield curve for GIIPS countries escalated above the rest. Stronger economic forces i.e. Germany, UK, Sweden and France (after June 2011) showed stable, less volatile movements, echoing tough action to combat deficit and stabilizing economy.

The upward pressure on domestic and foreign interest spreads of the bond markets of Eurozone was found to be driven by bad news. Spillovers of bad news were found to be evident coming from GIIPS countries onto non-GIIPS countries [13].

\subsection{Effects on Foreign Exchange Markets}

Whenever sovereign debt crisis risk increases in the Eurozone, euro depreciates against the US dollar. External value of the euro is more prone to changes in sovereign debt crisis risk in vulnerable member countries than in stable member countries. Moreover, rising default risk of medium and large Eurozone banks leads to a depreciation of the euro while small banks' default risk has no significant impact, showing the relevance of systemically important banks with regards to the exchange rate [14].

Empirical findings suggest that the strength of a currency is positively related to its economic-political stability. Increased country risk due to economic-political instability would lead investors to sell securities denominated in the country's currency and to repatriate funds, hence putting downward pressure on the currency. Since the crisis began, market confidence on Euro had been dangerously low. Bankruptcy of Greece also mattered into depreciation of Euro against all major currencies worldwide [15, 16].

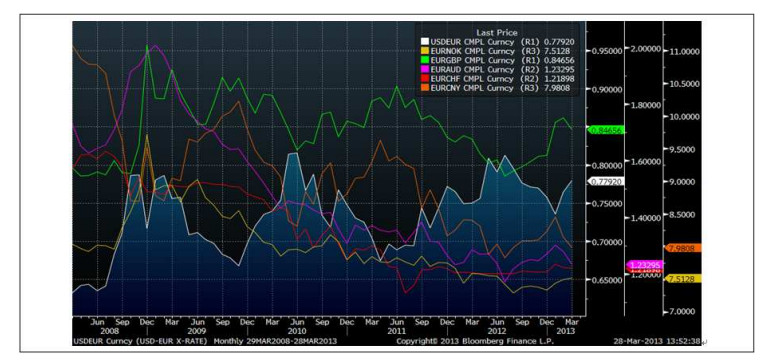

Figure 6. Euro cross exchange rates (Source: Bloomberg)

\subsection{Effects on Commodity Markets}

Gold is a renewable resource and, with no degradation in quality, could conceivably be recycled and contribute to a decrease in the global demand for newly mined gold [17]. Gold reserves in central banks are one of the largest sources of world gold supply. In comparison to other countries, USA holds the greatest amount of gold reserves in their central bank. Germany, France and Italy are the other major countries which individually keep gold bank reserves similar to the level of that held by the International Monetary Fund (IMF), around 3000 tones [18].

Shortly after the crisis began, gold spot prices have been continuously increasing. Despite some opposite movements, gold prices from 2008 and specifically since the inception of Eurozone crisis have had a fairly consistent upward trend. For the period of 2006 till 2012, gold spot prices saw a rise of almost $300 \%$. 


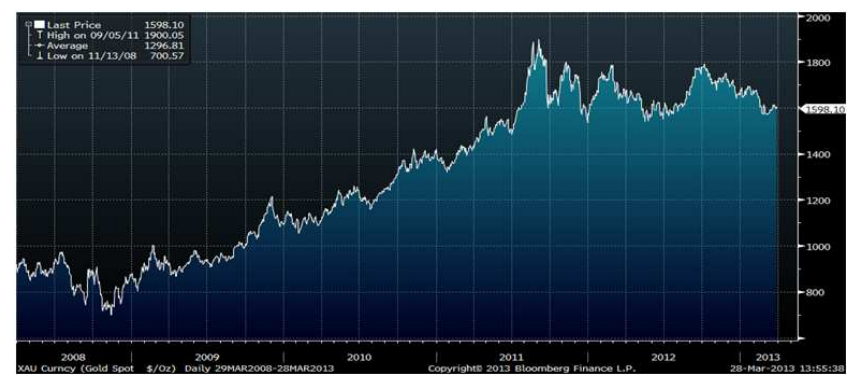

Figure 7. Gold spot price (Source: Bloomberg)

\section{Sovereign Defaults and Lessons}

Sovereign default refers to an event when a country is unable to repay its debts incurred from banks and investors. In such event, the country enters in a state of financial distress, which may lead to renegotiation or restructuring of debt [19]. This is mostly due to the lacking of any international bankruptcy law; as such renegotiation is most commonly used technique. A country has a higher probability of defaulting if they have significantly high debt/GDP ratio of its economy [20].

There have been extended study conducted on the losses of potential output due to sovereign debt crises. Research conducted over the period of 1970 to 2000 showed that almost 7\% yearly output losses incurred after large and long lasting sovereign crises hit the economies [21]. Defaulting also results in very high penalty costs for overall investment climate of the country, as investor confidence on those countries dives down. Even though Mexico and Russia has lower debt to GDP ratios, compared to countries i.e. Malaysia and Hungary, they have lower credit rating and higher bond spread.

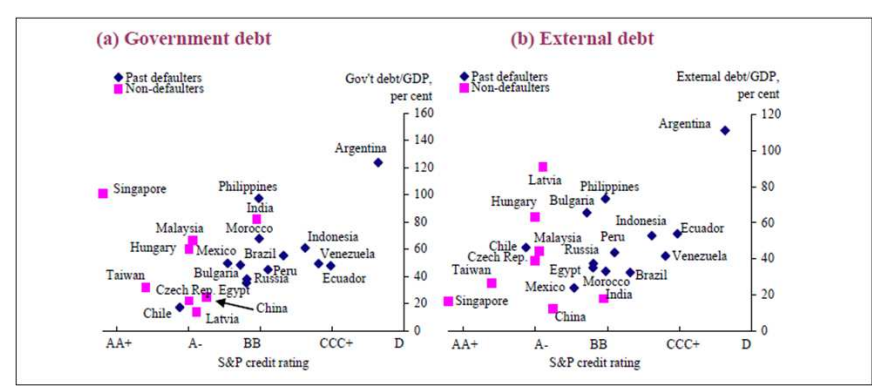

Figure 8. Debt/GDP \& Credit ratings during 2003-2005 [21]

Sovereign defaults generally occur in combination of sovereign debt, banking and currency crises. Defaulting is the ultimate stage of chaos arising from banking crises. That is evident in Argentina where banking crises followed by collapse of political system (three consecutive presidents in one month) contributed to fourth straight recession year [22].

Europe has suffered from the sovereign debt crisis mostly arising from issues i.e. toxic European Central Bank assets, exhausted monetary instruments and inadequate fiscal support, lack of pro-growth policies and challenges due to liquidity and insolvency to name a few. Following are some of the suggested ways defaulted countries outside the Eurozone (i.e. Argentina, Russia) can deal with sovereign default crisis:

- $\quad$ For most of the duration of the crisis, China, along with the other BRIC (Brazil, Russia, and India) nations is conditionally supporting Eurozone as an important trade partner and source of technology and foreign direct investment [23, 24, 25]. In order to cope with forecasted sovereign debt crisis related issues, defaulted countries should align and improve international relation with these strong emerging nations for future assistance.

- These defaulted countries should look to financial and fiscal integration to tackle default problems instead of looking up to simple monetary integration. However this level of integration especially in fiscal policies might result in a reduction of sovereignty [26].

- The following check list (figure 9) suggested to strengthen Eurozone can be applied for improving sovereign debt situation for these countries:

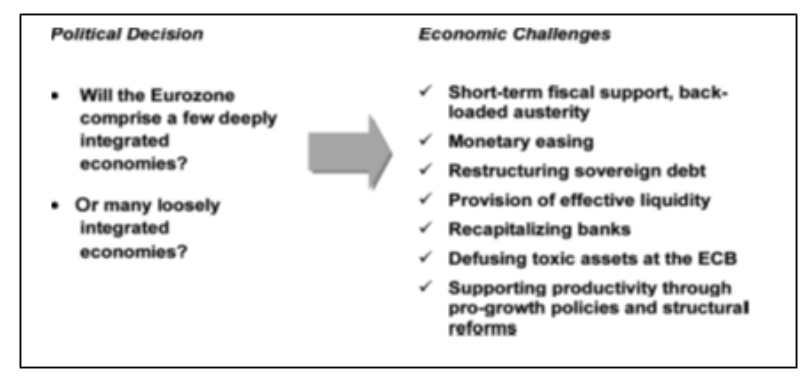

Figure 9. Checklist for sustained Eurozone [27]

\section{Eurozone Policies and Measures Taken to Address Sovereign Crisis}

Due to the fact that the sovereign crisis did not result from country's public debts itself, it is obvious that the underlying problem is laid on Eurozone's constitution and the health of individual economies. As a result, European Commission and its member states have taken several actions to tackle the economic turmoil.

In order to address liquidity problem arising from the financial crisis, a summit was held by the European Union in October 2008 which marked the agreement on a bank rescue plan aiming at boosting their financial situations and guaranteeing interbank lending. This protocol is considered a crucial coordination in preventing one country from harming other members and aggravating bank solvency and credit shortages.

Since Greece still suffered from lack of investor confidence in 2009 due to high fiscal deficit, which was admitted by its government to be understated at $3.7 \%$ of its GDP instead of the actual figure of $12.7 \%$ and its public debt (over $113 \%$ of the country's GDP and far more than the limit of $60 \%$ ), the sovereign debt crisis in early 2010 with Greece on the eye of the storm still needed to be intervened. Hence, another summit was held in 2011, in 
which the EU governments reached an agreement on an establishment of European Stability Mechanism and policy coordination to enhance the competitiveness of individual economies in short term [28]. Accordingly, the European Financial Stabilization Mechanism and the European Financial Stability Facility were imposed with the purpose of enabling the Commission and its member states to guarantee the loans of most fragile states that were in financial distress and to grant them bilateral loans which amounting to $€ 780$ billion. Furthermore, this commitment also authorized the Commission to intervene in the primary and secondary debt markets and the finance recapitalization of financial institutions through loans to governments. On the other hand, in order to deal with long-term prospects, nations came up with a harmony on a reform of Stability and Growth Pact and Euro Plus Pact to improve the economic health of individual nations and further prevent the crisis from happening again.

To conclude, various emergency measures taken by the European Commission and its member countries during two periods of 2008-2009 and 2009-2011 have been successful in terms of averting the global financial crisis and supporting short-term domestic demand. These facilities eventually improved the stock indices of the GIIPS from mid-2009 to late 2010 except for Greece (whose stock index decreased) and further helped to recover those nations' creditability and investor confidence, as illustrated in figure 10:

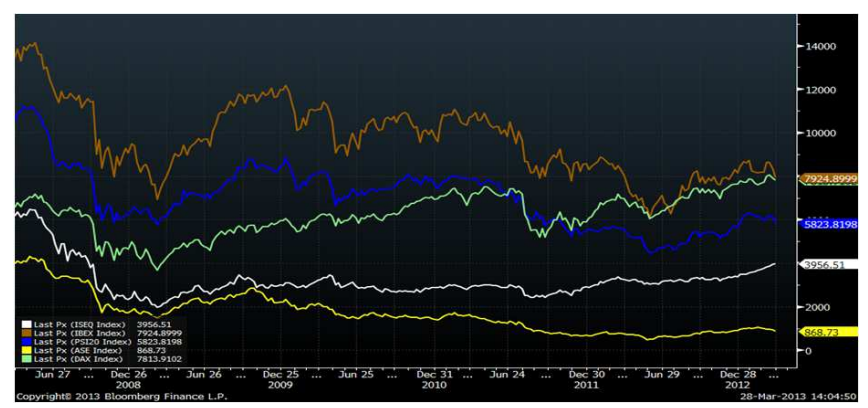

Figure 10. Stock indices of GIIPS group (Source: Bloomberg)

\section{Eurozone Crisis Implications}

As discussed above, the Eurozone crisis has caused severe turbulence not only among the peripheral countries but also the core ones. Furthermore, European nations contribute to average $27 \%$ of the world GDP, while the Eurozone itself comes up with approximately $19.4 \%$ and $26 \%$ of global holdings of reserves in Euro. Hence, this crisis is not merely significant in affecting European economy, but more essentially, it caused a threat to the recovery pace of global economy due to the fact that Eurozone is a prominent economic partner for the rest of the world. Unless actions are taken, the power of European economy is expected to shrink and lose half of its GDP contribution to the world economy as a whole in long-term [27].

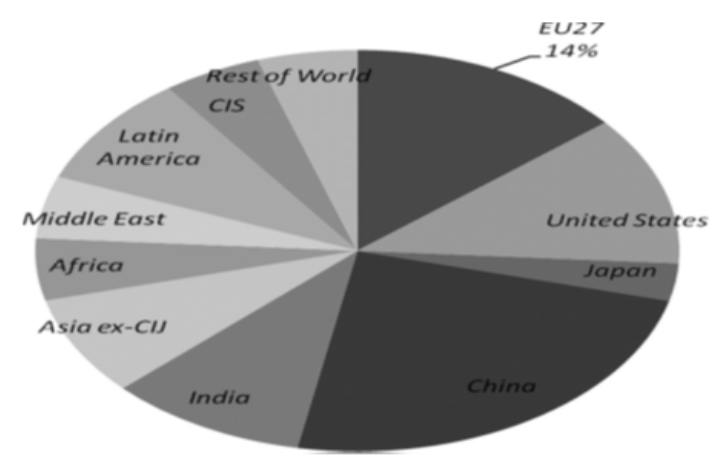

Figure 11. Projected shift of economic power in 2050 [27]

Moreover, it caused many changes in the financial markets in which the balance sheets of sovereign countries now require more attention in risk measurement by investors. Finally, the European debt crisis has curtailed the growth in economy and created extensive unemployment, consequently raising chances for investors to invest with high return as a result of cheaper and more flexible labor force and lower fixed costs.

\section{Future Directions}

This crisis has pointed out weaknesses in European financial system, which can be cured and improved for a further sustainable economy. Firstly, it has given opportunities for emerging countries to improve their monetary policies and procedures by encouraging the implementation of strong financial infrastructures. A strengthened domestic financial systems and institutions were recognized to play a vital role in sustaining the amount of public debts. As a supplementary idea, a reduction in vulnerabilities to liquidity risk and balance sheet risk in the common area by matching properly foreign reserves and liabilities can also be considered [29].

Alternatively, appropriate exchange rate regime and the advantages and disadvantages of both floating and fixed exchange rate should be taken into consideration by European governments. The fixed exchange rate allows local financial institutions to borrow in foreign currency then loan freely in that currency to domestic borrowers [30] However, when an economic turmoil occurs, the existing exchange rate will become unsustainable. Therefore, it is necessary for a country to have better forecast on the future and appropriate adjustment of exchange rate if it is to keep a fixed rate of exchange and a stable economy.

\section{References}

[1] EUROSTAT (2012). Euro Area and EU27 Government Deficit at $4.1 \%$ and $4.5 \%$ of GDP Respectively, EUROSTAT.

[2] Lewis, M. (2011). Boomerang: the meltdown tour, Penguin.

[3] Herring, R. and S. Wachter (2003). "Bubbles in real estate markets." Asset Price Bubbles: The Implications for Monetary, Regulatory, and International Policies: 217-227. 
[4] Reinhart, C. M. and K. Rogoff (2009). This time is different: Eight centuries of financial folly, Princeton University Press.

[5] Anand, M., G. L. Gupta, et al. (2012). The euro zone crisis Its dimensions and implications.

[6] Parrott, W. (2012). The European Debt Crisis. SA Technical. London, ACCA.

[7] Marsh, B. (2011). "It's all connected: an overview of the euro crisis." New York Times. Consulted on June 26: 2012.

[8] Sabnavis, M. and S. Paradkar (2011). Impact of Euro Crisis and Global Showdown on India. India, Care Ratings: Professional Risk Opinion.

[9] Pilbeam, K. (1998). Finance and financial markets, Macmillan Business.

[10] Ghosh, A. R., J. D. Ostry, et al. (2012). "Fiscal Space and Sovereign Risk Pricing in a Currency Union." Journal of International Money and finance.

[11] Skintzi, V. D. and A. N. Refenes (2006). "Volatility spillovers and dynamic correlation in European bond markets." Journal of International Financial Markets, Institutions and Money 16(1): 23-40.

[12] De Grauwe, P. and Y. Ji (2012). "Self-fulfilling crises in the Eurozone: An empirical test." Journal of International Money and finance.

[13] Beetsma, R., M. Giuliodori, et al. (2012). "Spread the News: the Impact of News on the European Sovereign Bond Markets during the Crisis." Journal of International Money and finance.

[14] Eichler, S. (2012). "The impact of banking and sovereign debt crisis risk in the eurozone on the euro/US dollar exchange rate." Applied Financial Economics 22(15): 1215-1232.

[15] Eun, C. S. and B. G. Resnick (2010). International financial management, Tata McGraw-Hill Education.

[16] Hui, C.-H. and T.-K. Chung (2011). "Crash risk of the euro in the sovereign debt crisis of 2009-2010." Journal of Banking \& Finance 35(11): 2945-2955.

[17] Batchelor, R. and D. Gulley (1995). "Jewellery demand and the price of gold." Resources Policy 21(1): 37-42.
[18] Shafiee, S. and E. Topal (2010). "An overview of global gold market and gold price forecasting." Resources Policy 35(3): 178-189.

[19] Banks, E. (2010). Finance: the basics, Routledge.

[20] Yue, V. Z. (2010). "Sovereign default and debt renegotiation." Journal of International Economics 80(2): 176-187.

[21] De Paoli, B., G. Hoggarth, et al. (2009). "Output costs of sovereign crises: some empirical estimates."

[22] Schamis, H. E. (2002). "Argentina: crisis and democratic consolidation." Journal of democracy 13(2): 81-94.

[23] Inman, P. (2012). Brazil's economy overtakes UK to become world's sixth largest. The Guardian.

[24] AFP (2013). Eyes on euro zone's firefighter. South China Morning Post South China Morning Post

[25] Harding, R. (2013). "Emerging markets dump euro reserves." Currencies. Retrieved 31-03-2013, from http://www.ft.com/cms/s/0/77ebfe6c-99f4-11e2-83ca-00144 feabdc0.html\#axzz2P8RWXpAZ.

[26] FES (2013). THE EURO DEBT CRISIS: CONSEQUENCES FOR THE GLOBAL ECONOMY AND IMPLICATIONS FOR EMERGING COUNTRIES. Dialogue on Globalization, Shanghai.

[27] Steinbock, D. (2012). "The Eurozone Debt Crisis: Prospects for Europe, China, and the United States." American Foreign Policy Interests 34(1): 34-42.

[28] Summers, L. H. (2000). "International financial crises: causes, prevention, and cures." The American Economic Review 90(2): 1-16.

[29] Johnson, S., P. Boone, et al. (2000). "Corporate governance in the Asian financial crisis." Journal of financial economics 58(1): 141-186.

[30] Calvo, G. and F. S. Mishkin (2003). The mirage of exchange rate regimes for emerging market countries, National Bureau of Economic Research.

[31] Madura, J. (2012). Financial markets and institutions, South Western Educational Publishing. 